\title{
Is The Begetting of Triplets Associated With The Developing of 3 Breast Primaries?
}

\author{
Wilson I B Onuigbo ${ }^{1 *}$ and Gabriel E Njeze ${ }^{2}$ \\ ${ }^{1}$ Departments of Pathology, University of Nigeria Teaching Hospital, Nigeria
}

Submission: December 08, 2016; Published: January 03, 2017

"Corresponding author: Wilson I B Onuigbo, Medical Foundation \& Clinic, 8 Nsukka Lane, Enugu 400001, Nigeria, Email: wilson.onuigbo@gmail.com

\begin{abstract}
A Birmingham (UK) group considered in 1980 that the establishment of a Histopathology data pool encourages epidemiologic analysis. Consequently, the senior author (WIBO) had such an advantageous opportunity. Interestingly, the junior author (GEN), working in a near Surgical Outpatient Clinic, was consulted by a gravid 5, para 8, patient, i.e., one twin and a set of triplets. Moreover, she also developed 3 breast carcinomas. Therefore, this paper is documented in order to stimulate worldwide interest in this peculiar combination. Is it only happenstance or an explicable natural event?
\end{abstract}

Keywords: Breast, triple cancer, pregnancy, triplets, Igbos, epidemiology

\section{Introduction}

The breast has for centuries been the medical man's talking point. Thus, as the physician/historian, Henry Sigerist, summed it up, "it was chiefly cancer of the breast that attracted the physician's attention" [1]. Today, one such point is multiple cancers developing especially in this organ [2]. Perhaps, a most engaging view is also the delivery of triplets [3]. Therefore, we are persuaded that, if the one (triplet) heralds the other (triple tumors), the documentation of both of them is likely to constitute a good goal for recondite research [4].

\section{Investigation}

It was stated by a Birmingham (UK) group (5) that the establishment of a histopathology data pool aids in epidemiological analysis. Accordingly, what has gone between the Pathology Laboratory and the Surgical Outpatient Department in the University Teaching Hospital, Enugu, is the case of a woman bearing triplets and later developing breast cancer of triple types.

\section{Case Report}

At the Surgical Outpatient Clinic, a 34-year-old woman attended with the complaint of feeling a lump in her right breast. The junior author (GEN) queried fibroadinosis. The lesion was a mobile, non-tender, ovoid, firm mass $7 \mathrm{~cm} \mathrm{x} 4 \mathrm{~cm}$ across with several tortuous veins on the skin over it. Menarche was at 18 years. The recent menses was 2 months before her attendance. Altogether, she was Gravida 5, Para 8 (1 twin delivery, 1 triplet delivery). At biopsy, the mass cut with a gritty feel. The obtained specimen was delivered to the senior author (WIBO), who discovered that there were 3 primaries, namely, invasive ductal carcinoma, papillary carcinoma, and medullar carcinoma.

\section{Discussion}

Here, there was set against the delivery of triplets the odd developing of triple carcinomas. Was this mere happenstance? Or, was Nature pointing to an explicable sequence? These questions are open to research. Incidentally, there is a known problem that arises in triplet pregnancy. It is described as a challenge in perinatal medicine [2]. However, we are dealing here with adult medicine, namely, the development of breast cancer not just in one but in three sites after the begetting of triplets.

\section{Conclusion}

One group [6], on looking anew at a nationwide study in Sweden, concluded that "Breast feeding patterns in mothers of twins also may modify their risk of developing breast cancer." However, emphasis should be made on triplet bearing patients. Unfortunately, work in USA [7] did not direct attention to such triplet's bearers. Triplets were examined by some groups with reference to mortality strictly $[8,9]$. However, what of its effect, if any, on the rarity of triplet births with regard to malignancy of the breast, especially when it is up to three different primaries? Future researches should provide the answer! 


\section{Cancer Therapy \& Oncology International Journal}

\section{References}

1. Sigerist HE (1892) The historical development of the pathology and therapy of cancer. Bull N Y Acad Med, 8(11): 642-653.

2. Ceres R, Atares A, Tarrio OF (1999) Triplet pregnancy: A difficult challenge in perinatal medicine. Am J Obstet Gynecol 180(3): 771-772.

3. Donatella Caserta, Giulia Bordi, Michele Stegagno, Francesca Filippini, Maria Podagrosi, et al. (2012) Study of a population of triplet pregnancies: Maternal and neonatal outcomes. J Neo Bio 1: 104.

4. Hsieh CC, Goldman M, Pavia M, Ekbom A, Petridou E, et al. (1993) Breast cancer risk in mothers of multiple births. Int J Cancer 54(1): 81-84.

5. Macartney JC, Rollaston TP, Codling BW (1980) Use of a histopathology data pool for epidemiological analysis. J Clin Pathol 33(4): 351-355.
6. Lambe M, Hsieh C, Tsaih S, Ekbom A, Adami HO, et al. (1996)Maternal risk of breast cancer following multiple briths: a nationwider study in Sweden. Cancer Causes Control 7(5): 533-538.

7. Dietz AT, Newcomb PA, Storer BA, Longnecker MP, Mittendorf R (1995) Multiple births and risk of breast cancer. Int J Cancer 62(2): 162-164.

8. Barr S, Poggi S, Keszler M (2003) Triplet morbidity and mortality in a large case series. J Perinatol 23(5): 368-371.

9. Ghulmiyyah LM, Perloe M, Tucker MJ, Zimmermann JH, Eller DP, et al. (2003) Monochorionic-triamniotic triplet pregnancy after intracytoplasmic sperm injection, assisted hatching, and two-embryo transfer: first reported case following IVF. BMC Pregnancy Childbirth 3(1): 4.

\begin{tabular}{l} 
Your next submission with JuniperPublishers \\
will reach you the below assets \\
- Quality Editorial service \\
- Swift Peer Review \\
- Reprints availability \\
- E-prints Service \\
- Manuscript Podcast for convenient understanding \\
- Global attainment for your research \\
- Manuscript accessibility in different formats \\
( Pdf, E-pub, Full Text, Audio) \\
- Unceasing customer service \\
Track the below URL for one-step submission \\
https://juniperpublishers.com/online-submission.php \\
\hline
\end{tabular}

